\title{
A 5’UTR polymorphism in NT5E gene but not fludarabine systemic exposure influences HCT outcome in patients with high-risk $\beta$-thalassemia major
}

\author{
Aswin Pai ${ }^{1}$, Ezhilpavai Mohanan ${ }^{1}$, John Panetta ${ }^{2}$, Balaji Balakrishnan ${ }^{1}$, Raveen Stephen \\ Illangeswaran ${ }^{1}$, Bharathi Rajamani ${ }^{1}$, Kavitha Lakshmi ${ }^{1}$, Eunice Edison ${ }^{1}$, Anu Korula ${ }^{1}$, \\ Fouzia $A^{1}$, Aby Abraham ${ }^{1}$, Biju George ${ }^{1}$, Alok Srivastava ${ }^{1}$, Vikram Mathews ${ }^{1}$, and \\ Poonkuzhali Balasubramanian ${ }^{1}$ \\ ${ }^{1}$ Christian Medical College \\ ${ }^{2}$ St. Jude Children's Research Hospital
}

January 18, 2021

\begin{abstract}
Aim Although the fludarabine (F-araA)-treosulfan based toxicity reduced conditioning regimen has improved hematopoietic cell transplantation (HCT) outcome in patients with high-risk beta-thalassemia major (TM), rejection and regimen related toxicities (RRT) are still of major concern. This study aims to assess the role of F-araA pharmacokinetics (PK) and pharmacogenetics $(\mathrm{PG})$ in a uniform cohort of patients with TM. Methods All patients with TM who receiving F-araA based regimen prior to HCT between September 2010 and 2019 were enrolled in this study. F-araA plasma levels were analyzed using LC-MS/MS. Selected polymorphisms in genes encoding for the enzymes (NT5E (Ecto-5'-nucleotidase) and DCK (Deoxycytidine kinase) involved in the metabolism of F-araA were screened. The influence of F-araA PK and PG on clinical outcomes were evaluated. Results F-araA PK showed wide inter-individual variation (27 and 19 fold in F-araA AUC and CL) which was explained by a promoter polymorphism (rs2295890) in the NT5E gene. Patients carrying the NT5E promoter variant showed no graft rejection ( $0 \%$ vs $7.7 \%, p=0.07$ ) or Sinusoidal Obstruction Syndrome (0\% Vs 19\%, p=0.0007) and a trend to better EFS ( $87.5 \%$ vs $75.7 \%$, $\mathrm{p}=0.1$ ). F-araA systemic exposure was not associated with HCT outcome. Conclusion Our results suggest that the NT5E promoter polymorphism could be a predictive biomarker in F-araA based HCT setting in TM, however extensive functional studies are warranted to validate the clinical utility of this finding.
\end{abstract}

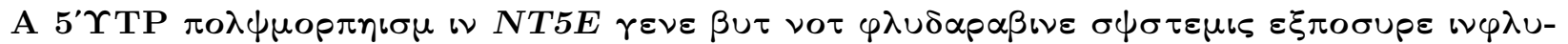

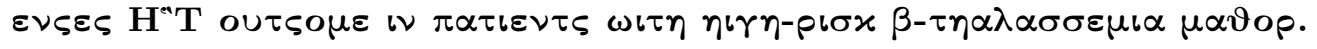

Aswin Anand Pai ${ }^{1,2^{*}}$, Ezhilpavai Mohanan ${ }^{1 *}$, John C Panetta ${ }^{3}$, Balaji Balakrishnan ${ }^{1}$, Raveen Stephen Stallon Illangeswaran ${ }^{1}$, Bharathi M Rajamani ${ }^{1}$, Kavitha M Lakshmi ${ }^{1}$, Eunice S Edison ${ }^{1}$, Anu Korula ${ }^{1}$, Fouzia $\mathrm{NA}^{1}$, Aby Abraham ${ }^{1}$, Biju George ${ }^{1}$, Alok Srivastava ${ }^{1}$, Vikram Mathews ${ }^{1}$, Poonkuzhali Balasubramanian ${ }^{1}$

${ }^{1}$ Christian Medical College, Vellore, India, ${ }^{2}$ Sree Chitra Tirunal Institute for Medical Sciences and Technology, Thiruvananthapuram, India $\&^{3}$ St. Jude Children's Research Hospital, Memphis, USA.

*- Equal contribution

\section{Correspondence:}

Poonkuzhali Balasubramanian, Ph.D.

Professor 
Department of Haematology

Christian Medical College- Vellore-632004

Phone : 914162283476

Fax : 914162226449

E-mail: bpoonkuzhali@cmcvellore.ac.in

ORCID ID : 0000-0002-9443-439X

\section{Short Title: POPPK of fludarabine in thalassemia}

\section{What is already known about this subject?}

- Despite improved HCT outcome in patients with high-risk TM using F-araA based regimen, rejection and toxicities still remain a major concern.

- Limited inconclusive data on F-araA PK in non-uniform diagnoses and dose-exposure response relationship was not evaluated in patients with high-risk TM.

- Sparse data on F-araA pharmacogenomics.

\section{What this study adds}

- Dose-exposure-response relationship of F-araA was evaluated in a large uniform cohort of patients with high-risk TM undergoing HCT.

- Wide Inter-individual variation in F-araA PK, partially explained by a genetic polymorphism in NT5E gene.

- F-araA PK did not explain variability in HCT outcome while patients carrying NT5E promoter variant had improved outcome and better survival.

- Our results suggest that NT5E polymorphism could be a predictive biomarker in F-araA based HCT setting in TM, however extensive functional studies are warranted to validate the clinical utility of this finding.

\section{Abstract}

\section{$\operatorname{Aim}$}

Although the fludarabine (F-araA)-treosulfan based toxicity reduced conditioning regimen has improved hematopoietic cell transplantation (HCT) outcome in patients with high-risk beta-thalassemia major (TM), rejection and regimen related toxicities (RRT) are still of major concern. This study aims to assess the role of F-araA pharmacokinetics (PK) and pharmacogenetics (PG) in a uniform cohort of patients with TM.

\section{Methods}

All patients with TM who receiving F-araA based regimen prior to HCT between September 2010 and 2019 were enrolled in this study. F-araA plasma levels were analyzed using LC-MS/MS. Selected polymorphisms in genes encoding for the enzymes (NT5E (Ecto-5'-nucleotidase) and DCK (Deoxycytidine kinase) involved in the metabolism of F-araA were screened. The influence of F-araA PK and PG on clinical outcomes were evaluated.

\section{Results}

F-araA PK showed wide inter-individual variation (27 and 19 fold in F-araA AUC and CL) which was explained by a promoter polymorphism (rs2295890) in the NT5E gene. Patients carrying the NT5Epromoter variant showed no graft rejection $(0 \%$ vs $7.7 \%, \mathrm{p}=0.07)$ or Sinusoidal Obstruction Syndrome $(0 \%$ Vs $19 \%$, $\mathrm{p}=0.0007)$ and a trend to better EFS $(87.5 \%$ vs $75.7 \%, \mathrm{p}=0.1)$. F-araA systemic exposure was not associated with HCT outcome.

\section{Conclusion}


Our results suggest that the NT5E promoter polymorphism could be a predictive biomarker in F-araA based HCT setting in TM, however extensive functional studies are warranted to validate the clinical utility of this finding.

\section{Introduction}

Hematopoietic cell transplantation (HCT) is the only proven curative modality available for patients with $\beta$-thalassemia major (TM). The ideal conditioning regimen for these patients, particularly those at high risk ${ }^{1}$ remains to be defined. A toxicity reduced conditioning regimen containing Treosulfan (Treo), Fludarabine (F-araA) and Thiotepa has significantly improved transplant outcomes compared to the historical Busulfan/cyclophosphamide $(\mathrm{Bu} / \mathrm{Cy})$ based myeloablative regimen in patients with high-risk $\mathrm{TM}^{1,2}$. However, graft rejection, RRTs, and Graft Versus Host Disease (GvHD) $)^{3,4}$ are still a major concern. Limited inconclusive data is available on the PK, pharmacogenetics (PG) and pharmacodynamics of F-araA ${ }^{5-11}$ or Treo ${ }^{12-19}$ in patients undergoing HCT with this regimen in patients with varying diagnoses. All these studies including ours have shown wide inter-individual variation in F-araA and Treo PK but none of the variables tested explained this variation. In our recent report on F-araA PK in patients with aplastic anemia/Fanconi anemia $^{9}$, a promoter polymorphism (rs2295890G $>$ C) in the 5'ectonucleotidase (NT5E /CD73) gene, which is involved in the conversion of prodrug Fludarabine monophosphate to F-araA significantly explained this variation.

While the role of conditioning regimen drug exposure on HCT outcome has been extensively evaluated with respect to $\mathrm{Bu} / \mathrm{Cy}$ regimen resulting in targeted dose adjustment of $\mathrm{Bu}$ to improve outcome ${ }^{20-23}$, no such effort has yet been made for toxicity reduced conditioning regimen containing Treo/Flu/Thiotepa. Here we evaluated the PK and PG of F-araA and the role of these variables in influencing the inter-individual variability in PK and its influence on HCT outcome in a uniform cohort of patients with high-risk TM.

\section{Patients and Methods}

\section{Patients:}

Patients with high-risk TM receiving F-araA based conditioning regimen prior to HCT between 2010 and 2019 were recruited after obtaining written informed assent or consent from the patient/parents respectively. This study was approved by the Institutional review board. All patients were risk-stratified based on Vellore risk classification as published previously ${ }^{24}$. All patients received F-araA at a dose of $40 \mathrm{mg} / \mathrm{m}^{2} /$ day x 4 days as $1 \mathrm{hr}$ infusion from day -5 to day -2 and Treo as $14 \mathrm{~g} / \mathrm{m}^{2} /$ day $\mathrm{x} 3$ days at the rate $5 \mathrm{~g} / \mathrm{hr}$ from day -5 to day -3 and a single dose of Thiotepa on day -6 prior to HCT. Cyclosporine and short course methotrexate was used as GVHD prophylaxis ${ }^{1}$.

\section{Pharmacokinetics and pharmacogenetics of F-araA}

Heparinized peripheral blood $(5 \mathrm{~mL})$ was collected from the patients before and after the start of F-araA infusion on day -5 at specific time points $(\mathrm{n}=5)$. The plasma was obtained by centrifuging at 3000rpm for 5 minutes and stored at $-80^{\circ} \mathrm{C}$ until analysis. F-araA levels in plasma samples were measured by LC-MS/MS as reported previously ${ }^{9}$. Similar to our previous study ${ }^{9}$, selected polymorphisms in the NT5E(rs2295890) and deoxycytidine kinase, DCK (rs11544786) genes (with an allele frequency of $>0.1$ based on 1000 genome database or with clinical significance) encoding the rate-limiting enzymes in the F-araA metabolic pathway were screened using the pre-HCT genomic DNA by followed by Sanger sequencing.

\section{Population pharmacokinetics (POPPK) of F-araA}

Non-linear mixed effects modeling analysis was performed via Monolix (version 5.1.0) using the Stochastic Approximation Expectation-Maximization (SAEM) method. A two-compartment PK model was used to describe the data. The PK parameters estimated included clearance, CL $\left(\mathrm{L} / \mathrm{hr} / \mathrm{m}^{2}\right)$ and volume, V $\left(\mathrm{L} / \mathrm{m}^{2}\right)$ along with the inter-compartmental clearance and peripheral compartment volume $\left(\mathrm{Q}\left(\mathrm{L} / \mathrm{hr} / \mathrm{m}^{2}\right)\right.$ and $\mathrm{V}_{2}$ $\left.\left(\mathrm{L} / \mathrm{m}^{2}\right)\right)$. In addition, the individual post-hoc parameter values were used to estimate the area under the concentration curve (AUC). The inter-individual variability of the parameters was assumed to be log-normally 
distributed. A combined additive and proportional residual error model was used with assumed normal distribution of the residuals.

The relationships between the PK parameters and covariates were described using the following model: $\vartheta=\vartheta_{\text {Base }}{ }^{*} \exp \left(\beta^{*}\right.$ covariate $)$. A covariate was considered significant in the Univariate analysis, if the addition of the covariate to the model reduced the objective function value (OFV) at least 3.84 units $(p<0.05$, based on the $\chi^{2}$ test for the difference in the -2 log-likelihood between two hierarchical models that differ by 1 degree of freedom).

\section{Clinical Outcome :}

HCT outcomes such as RRTs, engraftment, rejection, GVHD, donor-recipient chimerism status, and survival status were documented. The potential factors influencing these outcome parameters were evaluated. An absolute neutrophil count of $>500 \times 10^{6} / \mathrm{L}$ on three consecutive days was noted as neutrophil engraftment; day +28 chimerism analysis showing more than $95 \%$ of donor genetic marker patterns was considered as achieving complete chimerism (CC). Mixed Chimerism (MC) was defined as the presence of $>5 \%$ residual host chimerism at any time point post $\mathrm{HCT}$, whereas rejection as $>90 \%$ residual host chimerism in peripheral blood as described previously ${ }^{25}$. The RRTs including mucositis was graded according to NCI-CTCAE V5.0 criteria ${ }^{26}$, Hepatic Sinusoidal Obstruction Syndrome (SOS) was graded according to Baltimore criteria 27. GVHD was graded using Glucksberg criteria ${ }^{27}$. Any deaths occurring within the first 100-days post HCT was regarded as Transplant Related Mortality (TRM). Early TRM (TRM D+30) and late TRM $(\mathrm{TRM}+100)$ are deaths occurring within 30 and 100 days post-transplantation mostly due to RRTs and infections. Event-free survival (EFS) was defined from the time of transplant to an event; an event was primary graft rejection/failure, death. Overall survival (OS) was defined as the percentage of patients who were alive at the last follow-up.

\section{Statistical analyses:}

All statistical analyses were performed by IBM SPSS statistics 21.0 (IBM Corp. Armonk, NY, USA), R Statistical software (version 4.0.3; R Foundation for Statistical Computing, Vienna, Austria), and GraphPad PRISM5 software (GraphPad Software Inc, San Diego, CA, USA). Fisher's exact test and Pearson's chisquare test were used for individual parameter analysis. For testing the association between polymorphism and outcomes, we used Firth logistic regression that uses a penalized likelihood to remove much of the bias from the maximum likelihood estimates in the logistic regression model ${ }^{28}$. This method is best suited for the present study as the genetic variants tested are rare. Log Rank Mantel-Cox regression analysis was used for the survival analysis.

\section{Results}

\section{Patient Demographics}

Between November 2010 and 2019, 281 patients with TM underwent HCT in our centre. Of these, patients who gave consent to participate in the study, as well as those with follow-up, were enrolled for the PK study $(n=169)$. There was no significant difference in demographics between the patients with high-risk TM enrolled in the PK study compared to the total number of patients with high-risk TM who underwent HCT during the study period. (Table-S2) Two hundred and eighty-one patients with high-risk TM underwent HCT with Thio/F-araA/Treo conditioning regimen during the study period. Their median age was 9yrs (1-25yrs). Majority of the patients belonged to class III (Class III High Risk-48\%; class III Low risk-39\%) and $12 \%$ of patients belonged to class II. The demographics of these patients are summarized in Table 1.

\section{F-araA PopPK and PG:}

F-araA PK was available for 169 patients enrolled in the study. Thirty-two (11.7\%) and $19(10.3 \%)$ patients carried variant allele for NT5E and DCK polymorphisms. The population pharmacokinetic parameters are shown in Table 2. The median post hoc estimated F-araA AUC and CL for the first dose was 19 (3-81) $\mu \mathrm{mol} * \mathrm{~h} / \mathrm{mL}$ and $7(2-38) \mathrm{L} / \mathrm{h} / \mathrm{m}^{2}$. The PopPK model estimated significant inter-individual variation (IIV) in 
F-araA PK (27 and 19 fold in AUC and CL). F-araA Cl was significantly lower in patients with NT5Evariant rs2295890 genotype ( $5.37 \mathrm{vs} 7.17 \mathrm{~L} / \mathrm{h} / \mathrm{m}^{2} ; \mathrm{p}=0.001$ ). These differences translated to significantly higher AUC in patients with variant rs2295890 genotype (26.5 vs $\left.18.0 \mu \mathrm{M}^{*} \mathrm{~h} ; \mathrm{p}=0.01\right)$ (Figure 1). The NT5E variant explained $4.5 \%$ of the IIV on the clearance of F-araA. None of the other demographic/biochemical covariates including $D C K$ polymorphism explained IIV in F-araA PK.

\section{HCT outcome:}

HCT outcome endpoints are listed in Table-S1. Patients were followed up for a median of 30 (0.3-108) months. Fourteen patients (5.0\%) died early due to RRT and other transplantation-related complications, while 267 patients had documented engraftment (median day of engraftment was 16 days (range: 10-43 days). Post-transplant hematopoietic chimerism evaluated in all patients who were alive beyond day +28 post HCT $(\mathrm{n}=264)$ showed complete chimerism (CC) in 239 (90.5\%), and mixed chimerism (MC) (3-97\% recipient cells) in $25(9.5 \%)$ on day +28 post HCT. Twenty-two of the 264 evaluable patients $(8.3 \%)$ rejected their graft with the median time of rejection of 2 months (0.7-14.2 months). Hepatic SOS and mucositis were documented in $54(19.2 \%)$ and 146 patients (I-2.8\%, II- 25.2\%, III- 22.7\% IV-1.06\%) respectively. Seventy-two $(25.6 \%)$ patients developed acute GVHD while thirty-one (11\%) had chronic GVHD. Overall, $225(80 \%)$ patients were alive at the last follow-up and the median event-free survival (EFS) was $76.8 \%$. Fifty-six patients died before day +100 (D+100 TRM). The major causes of death were steroid refractory GVHD (35.7\%), sepsis (33.9\%), and fungal infections (12.5\%), SOS (10.7\%), and multi-organ failure (7.1\%).

\section{Role of F-araA PK and PG on HCT outcome:}

None of F-araA PK parameters was associated with OS, EFS, TRM, and RRTs in 169 patients for whom PK data was available. Interestingly, patients carrying the $N T 5 E$ promoter variant (rs2295890) showed a trend to no rejection ( $0 \%$ vs $7.7 \%, \mathrm{p}=0.07$ ), better EFS ( $87.5 \%$ vs $75.7 \%, \mathrm{p}=0.1$ ), lower late TRM $\mathrm{D}+100$ ( $0.3 \%$ vs $12.5 \%, \mathrm{p}=0.08)$, better OS $(89.7 \%$ vs $78 \%, \mathrm{p}=0.25)$ and lower early TRM $\mathrm{D}+30(0.3 \%$ vs $8.8 \%$, $\mathrm{p}=0.2$ ) (Figure 2). Additionally, none of the patients carrying the NT5E promoter variant developed SOS compared to those with wild-type genotype for this variant ( $0 \%$ Vs $19 \%, p=0.0007)$. Logistic regression using the penalized maximum likelihood estimation method highlighted that NT5E promoter variant (rs2295890) has a protective effect on HCT outcome(Table-3) . No association was observed between DCK polymorphism and outcomes.

\section{Discussion :}

Although the toxicity-reduced conditioning regimen containing F-araA/Treo/Thiotepa has a favorable toxicity profile and has shown to improve HCT outcome in high-risk TM patients ${ }^{1}$, graft rejection and RRTs still present a roadblock in a subset of patients ${ }^{3,4}$. In this first single centre study, we have evaluated the PK and PG as well as the dose-exposure-response relationship to F-araA in a large uniform cohort of patients with high-risk TM undergoing HCT.

F-araA PK has been reported previously in patients undergoing HCT for both malignant, benign conditions and in various combination ${ }^{7-11,29-34}$. Despite wide IIV in F-araA PK in the present study, none of the biochemical or demographic parameters explained this variability. Previous F-araA PopPK studies have identified Glomerular filtration rate (GFR) ${ }^{11,34}$ and creatinine clearance ${ }^{8,10}$ as significant predictors of F-araA CL. In the present study, we did not include GFR as a covariate in the PopPK model as the patients enrolled in the study had a normal renal function and all the patients received a fixed initial dose of FaraAMP. The dose of F-araA used and the PK parameters in the present study are comparable to the existing reports (Table 4).

Although the dose-exposure response relationship has been explored previously for $\mathrm{Bu}{ }^{35-40}, \mathrm{Cy}{ }^{41,42}$, and Treo ${ }^{43}$, no such attempt had been made for F-araA in patients with TM. Several studies have described the influence of F-araA PK in HCT outcomes, albeit majority of the studies were conducted in patients undergoing HCT for malignant conditions ${ }^{6,7,10}$. A recent study carried out in a mixed cohort of patients with malignant and non-malignant ${ }^{34}$ conditions did not identify any relationship between F-araA PK and 
HCT outcomes. Despite significant IIV in F-araA PK observed in the present study, none of the F-araA PK parameters was associated with HCT outcomes. This could probably be because of the decreased incidence of events such as rejection or TRM in this non-malignant condition. A recent study in F-araA PK also predicted optimal cumulative exposure of $20 \mathrm{mg}^{*} \mathrm{~h} / \mathrm{L}$ for better EFS, lower TRM, and lower rejection ${ }^{44}$. However, the study cohort was heterogeneous, and the optimal exposure range was not confirmed in an independent cohort ${ }^{44}$.

Genetic variants in drug-metabolizing enzymes and transporters may also contribute to PK variability, which in turn could influence HCT outcome. Similar to our previous report on F-araA PK in patients with AA/FA undergoing $\mathrm{HCT}^{9}$, the patients carrying rs2295890 variant genotype exhibited significantly lower plasma F-araA CL compared to those with wild-type genotype in the present study (Figure 1) . This variant also explained $4.5 \%$ of the IIV in F-araA clearance in the POPPK model. Apart from its role in the biotransformation of $\mathrm{F}$-araA $\mathrm{A}^{45}, N T 5 E / C D 73$ is a multifunctional ectoenzyme involved in immunosuppression ${ }^{46}$, cancer progression ${ }^{47}$, and tumor microenvironment ${ }^{48,49}$. When we compared the role of this polymorphism on HCT outcomes, we observed that patients carrying the rs2295890 variant genotype showed better OS, EFS, lower rejection and lower TRM, consistent with our previous finding in AML cohort ${ }^{50}$. Low NT5E activity has been reported to be associated with a good prognosis in many malignancies ${ }^{46,51,52}$ probably due to the production of less adenosine that suppresses antitumor immunity and by not contributing to metastasis. The role of NT5E activity in HCT setting has not been explored except for few mice model studies, where it was suggested that low NT5E activity could lead to GvL/GvT (Graft Versus Leukemia/Tumor) phenomenon favoring HCT outcome, again reinstating the probable role of Adenosine 5'-triphosphate (ATP)-Adenosine axis in transplant immunology ${ }^{53-56}$. We could thus hypothesize that due to the reduced NT5E activity in patients carrying the variant genotype for this polymorphism, there is a lower production of adenosine and higher extracellular ATP activity, which in turn could prevent graft rejection and help in immunosuppression, eventually favoring better HCT outcome. In addition, we observed that none of the patients carrying the rs2295890 variant genotype had SOS. This could also be due to decreased NT5Eactivity in patients carrying the variant genotype for this polymorphism resulting in decreased production of adenosine, thus protecting the liver from fibrosis ${ }^{57,58}$. However, the exact mechanism between decreased NT5E activity and SOS needs to be explored further for its implication in pharmacogenetics testing as a plausible biomarker for HCT outcome.

\section{Conclusion:}

Our study demonstrates that F-araA PK does not predict HCT outcome in patients with high-risk TM. NT5E promoter polymorphism could be a predictive biomarker in F-araA based HCT setting in TM; however, extensive functional studies are warranted to validate the clinical utility of this finding.

\section{Acknowledgments}

Technical assistance provided by Mr. Rajesh, Ms. Shareen Stella, and Ms. Agila is gratefully acknowledged. We thank all the medical and nursing staff who managed the transplant patients.

\section{Conflict of Interest}

The authors declare no conflict of interest.

\section{Funding:}

This study is supported by grants from the Department of Biotechnology, India BT/PR1387/MED/12/515/2011 and Wellcome DBT India Alliance (IA/S/15/1/501842) to PB.

$\mathrm{PB}$ and VM are supported by the senior fellowship program of Wellcome DBT India Alliance (IA/S/15/1/501842 and IA/CPHS/18/1/503930 respectively). AAP is supported by Senior Research Fellowship from DBT, India.

\section{Contributors}


A.A.P., E.M., P.B., J.C.P., A.S., and V.M. wrote the article; P.B. designed the research; A.A.P., E.M., P.B., J.C.P., B.B., R.S.S.I., B.R.R., E.S.E., A.K., F.N., A.A., A.V., B.G., A.S., and V.M. performed the research; A.A.P., E.M., P.B., and K.M.L. analyzed and interpreted the data. All authors contributed to the writing of the manuscript, provided critical review, and approved the final version.

\section{Data Availability Statement}

The data that support the findings of this study are available from the corresponding author upon reasonable request.

\section{References}

1. Mathews V, George B, Viswabandya A, et al. Improved clinical outcomes of high risk $\beta$ thalassemia major patients undergoing a HLA matched related allogeneic stem cell transplant with a treosulfan based conditioning regimen and peripheral blood stem cell grafts. PloS One . 2013;8(4):e61637. doi:10.1371/journal.pone.0061637

2. Lucarelli G, Galimberti M, Delfini C, et al. MARROW TRANSPLANTATION FOR THALASSAEMIA FOLLOWING BUSULPHAN AND CYCLOPHOSPHAMIDE. The Lancet . 1985;325(8442):1355-1357. doi:10.1016/S0140-6736(85)91784-2

3. George B, Viswabandya A, Abraham A, et al. Increased Incidence of Mixed Chimerism with the Use of Fludarabine - Treosulfan Based Conditioning in Patients Undergoing Allogeneic Stem Cell Transplantation for Thalassaemia Major. Biol Blood Marrow Transplant . 2015;21(2):S284-S285. doi:10.1016/j.bbmt.2014.11.451

4. George B, Abraham A, Lakshmi K, et al. Treosulfan Based Conditioning Regimen Is Associated with Better Overall Survival Compared to Busulfan Based Regimens in Older Children with Thalassaemia Major. Biol Blood Marrow Transplant . 2019;25(3, Supplement):S317-S318. doi:10.1016/j.bbmt.2018.12.649

5. Salinger DH, Blough DK, Vicini P, et al. A limited sampling schedule to estimate individual pharmacokinetic parameters of fludarabine in hematopoietic cell transplant patients. Clin Cancer Res Off J Am Assoc Cancer Res . 2009;15(16):5280-5287. doi:10.1158/1078-0432.CCR-09-0427

6. McCune JS, Woodahl EL, Furlong T, et al. A pilot pharmacologic biomarker study of busulfan and fludarabine in hematopoietic cell transplant recipients. Cancer Chemother Pharmacol . 2012;69(1):263-272. doi:10.1007/s00280-011-1736-3

7. Long-Boyle JR, Green KG, Brunstein CG, et al. High fludarabine exposure and relationship with treatment-related mortality after nonmyeloablative hematopoietic cell transplantation. Bone Marrow Transplant . 2011;46(1):20-26. doi:10.1038/bmt.2010.53

8. Sanghavi K, Wiseman A, Kirstein MN, et al. Personalized fludarabine dosing to reduce nonrelapse mortality in hematopoietic stem-cell transplant recipients receiving reduced intensity conditioning. Transl Res J Lab Clin Med . 2016;175:103-115.e4. doi:10.1016/j.trsl.2016.03.017

9. Mohanan E, Panetta JC, Lakshmi KM, et al. Population pharmacokinetics of fludarabine in patients with aplastic anemia and Fanconi anemia undergoing allogeneic hematopoietic stem cell transplantation. Bone Marrow Transplant . Published online May 8, 2017. doi:10.1038/bmt.2017.79

10. Ivaturi V, Dvorak CC, Chan D, et al. Pharmacokinetics and Model-Based Dosing to Optimize Fludarabine Therapy in Pediatric Hematopoietic Cell Transplant Recipients. Biol Blood Marrow Transplant J Am Soc Blood Marrow Transplant . 2017;23(10):1701-1713. doi:10.1016/j.bbmt.2017.06.021

11. Langenhorst JB, Dorlo TPC, van Maarseveen EM, et al. Population Pharmacokinetics of Fludarabine in Children and Adults during Conditioning Prior to Allogeneic Hematopoietic Cell Transplantation.Clin Pharmacokinet . 2019;58(5):627-637. doi:10.1007/s40262-018-0715-9 
12. Scheulen ME, Hilger RA, Oberhoff C, et al. Clinical phase I dose escalation and pharmacokinetic study of high-dose chemotherapy with treosulfan and autologous peripheral blood stem cell transplantation in patients with advanced malignancies. Clin Cancer Res Off J Am Assoc Cancer Res . 2000;6(11):4209-4216.

13. Casper J, Freund M. Treosulfan based conditioning for autologous and allogeneic hematopoietic stem cell transplantation. Int J Clin Pharmacol Ther . 2004;42(11):661-662.

14. Hilger RA, Baumgart J, Scheulen ME, et al. Pharmacokinetics of treosulfan in a myeloablative combination with cyclophosphamide prior to allogeneic hematopoietic stem cell transplantation. Int $J$ Clin Pharmacol Ther . 2004;42(11):654-655.

15. Nemecek ER, Guthrie KA, Sorror ML, et al. Conditioning with treosulfan and fludarabine followed by allogeneic hematopoietic cell transplantation for high-risk hematologic malignancies. Biol Blood Marrow Transplant J Am Soc Blood Marrow Transplant . 2011;17(3):341-350. doi:10.1016/j.bbmt.2010.05.007

16. Główka FK, Romański M, Teżyk A, Zaba C, Wróbel T. HPLC method for determination of biologically active epoxy-transformers of treosulfan in human plasma: pharmacokinetic application. $J$ Pharm Biomed Anal . 2012;62:105-113. doi:10.1016/j.jpba.2011.12.021

17. ten Brink MH, Ackaert O, Zwaveling J, et al. Pharmacokinetics of Treosulfan in Pediatric Patients Undergoing Hematopoietic Stem Cell Transplantation: Ther Drug Monit . Published online January 2014:1. doi:10.1097/FTD.0000000000000047

18. Główka F, Kasprzyk A, Romański M, et al. Pharmacokinetics of treosulfan and its active monoepoxide in pediatric patients after intravenous infusion of high-dose treosulfan prior to HSCT. Eur J Pharm Sci Off J Eur Fed Pharm Sci . 2015;68:87-93. doi:10.1016/j.ejps.2014.12.010

19. Koyyalamudi SR, Kuzhiumparambil U, Nath CE, et al. Development and Validation of a High Pressure Liquid Chromatography-UV Method for the Determination of Treosulfan and Its Epoxy Metabolites in Human Plasma and Its Application in Pharmacokinetic Studies. J Chromatogr Sci . 2016;54(3):326-333. doi:10.1093/chromsci/bmv145

20. Bartelink IH, van Reij EML, Gerhardt CE, et al. Fludarabine and exposure-targeted busulfan compares favorably with busulfan/cyclophosphamide-based regimens in pediatric hematopoietic cell transplantation: maintaining efficacy with less toxicity. Biol Blood Marrow Transplant J Am Soc Blood Marrow Transplant . 2014;20(3):345-353. doi:10.1016/j.bbmt.2013.11.027

21. Perkins JB, Kim J, Anasetti C, et al. Maximally tolerated busulfan systemic exposure in combination with fludarabine as conditioning before allogeneic hematopoietic cell transplantation. Biol Blood Marrow Transplant J Am Soc Blood Marrow Transplant . 2012;18(7):1099-1107. doi:10.1016/j.bbmt.2011.12.584

22. Russell JA, Kangarloo SB, Williamson T, et al. Establishing a target exposure for once-daily intravenous busulfan given with fludarabine and thymoglobulin before allogeneic transplantation. Biol Blood Marrow Transplant J Am Soc Blood Marrow Transplant . 2013;19(9):1381-1386. doi:10.1016/j.bbmt.2013.07.002

23. McCune JS, Jacobson P, Wiseman A, Militano O. Optimizing drug therapy in pediatric SCT: focus on pharmacokinetics. Bone Marrow Transplant . 2015;50(2):165-172. doi:10.1038/bmt.2014.235

24. Mathews V, George B, Deotare U, et al. A new stratification strategy that identifies a subset of class III patients with an adverse prognosis among children with beta thalassemia major undergoing a matched related allogeneic stem cell transplantation. Biol Blood Marrow Transplant J Am Soc Blood Marrow Transplant . 2007;13(8):889-894. doi:10.1016/j.bbmt.2007.05.004

25. Fouzia NA, Edison ES, Lakshmi KM, et al. Long-term outcome of mixed chimerism after stem cell transplantation for thalassemia major conditioned with busulfan and cyclophosphamide. Bone Marrow Transplant . 2018;53(2):169-174. doi:10.1038/bmt.2017.231 
26. Common Terminology Criteria for Adverse Events (CTCAE) | Protocol Development | CTEP. Accessed October 13, 2020. https://ctep.cancer.gov/protocolDevelopment/electronic_applications/ctc.htm\#ctc_60

27. Carreras E, Dufour C, Mohty M, Kröger N, eds. The EBMT Handbook: Hematopoietic Stem Cell Transplantation and Cellular Therapies . 7th ed. Springer; 2019. Accessed October 13, 2020. http://www.ncbi.nlm.nih.gov/books/NBK553942/

28. Wang X. Firth logistic regression for rare variant association tests. Front Genet . 2014;5. doi:10.3389/fgene.2014.00187

29. Bornhäuser M, Storer B, Slattery JT, et al. Conditioning with fludarabine and targeted busulfan for transplantation of allogeneic hematopoietic stem cells. Blood . 2003;102(3):820-826. doi:10.1182/blood-200211-3567

30. Bonin M, Pursche S, Bergeman T, et al. F-ara-A pharmacokinetics during reduced-intensity conditioning therapy with fludarabine and busulfan. Bone Marrow Transplant . 2007;39(4):201-206. doi:10.1038/sj.bmt.1705565

31. Bemer MJ, Sorror M, Sandmaier BM, O'Donnell PV, McCune JS. A pilot pharmacologic biomarker study in HLA-haploidentical hematopoietic cell transplant recipients. Cancer Chemother Pharmacol . 2013;72(3):607-618. doi:10.1007/s00280-013-2232-8

32. McCune JS, Vicini P, Salinger DH, et al. Population pharmacokinetic/dynamic model of lymphosuppression after fludarabine administration. Cancer Chemother Pharmacol . 2015;75(1):67-75. doi:10.1007/s00280014-2618-2

33. McCune JS, Mager DE, Bemer MJ, Sandmaier BM, Storer BE, Heimfeld S. Association of fludarabine pharmacokinetic/dynamic biomarkers with donor chimerism in nonmyeloablative HCT recipients. Cancer Chemother Pharmacol . 2015;76(1):85-96. doi:10.1007/s00280-015-2768-x

34. Chung H, Hong KT, Lee JW, et al. Pharmacokinetics of fludarabine and its association with clinical outcomes in paediatric haematopoietic stem cell transplantation patients. Bone Marrow Transplant . 2019;54(2):284-292. doi:10.1038/s41409-018-0260-z

35. Poonkuzhali B, Srivastava A, Quernin MH, et al. Pharmacokinetics of oral busulphan in children with beta thalassaemia major undergoing allogeneic bone marrow transplantation. Bone Marrow Transplant . 1999;24(1):5-11. doi:10.1038/sj.bmt.1701814

36. Chandy M, Balasubramanian P, Ramachandran SV, et al. Randomized trial of two different conditioning regimens for bone marrow transplantation in thalassemia-the role of busulfan pharmacokinetics in determining outcome. Bone Marrow Transplant . 2005;36(10):839-845. doi:10.1038/sj.bmt.1705151

37. Gaziev J, Nguyen L, Puozzo C, et al. Novel pharmacokinetic behavior of intravenous busulfan in children with thalassemia undergoing hematopoietic stem cell transplantation: a prospective evaluation of pharmacokinetic and pharmacodynamic profile with therapeutic drug monitoring. Blood . 2010;115(22):4597-4604. doi:10.1182/blood-2010-01-265405

38. Poonkuzhali B, Chandy M, Srivastava A, Dennison D, Krishnamoorthy R. Glutathione S-transferase activity influences busulfan pharmacokinetics in patients with beta thalassemia major undergoing bone marrow transplantation. Drug Metab Dispos Biol Fate Chem . 2001;29(3):264-267.

39. Chiesa R, Cappelli B, Crocchiolo R, et al. Unpredictability of Intravenous Busulfan Pharmacokinetics in Children Undergoing Hematopoietic Stem Cell Transplantation for Advanced Beta Thalassemia: Limited Toxicity with a Dose-Adjustment Policy. Biol Blood Marrow Transplant . 2010;16(5):622-628. doi:10.1016/j.bbmt.2009.11.024

40. Balasubramanian P, Chandy M, Krishnamoorthy R, Srivastava A. Evaluation of existing limited sampling 
models for busulfan kinetics in children with beta thalassaemia major undergoing bone marrow transplantation. Bone Marrow Transplant . 2001;28(9):821-825. doi:10.1038/sj.bmt.1703245

41. Balasubramanian P, Desire S, Panetta JC, et al. Population pharmacokinetics of cyclophosphamide in patients with thalassemia major undergoing HSCT. Bone Marrow Transplant . 2012;47(9):1178-1185. doi:10.1038/bmt.2011.254

42. McCune JS, Batchelder A, Deeg HJ, et al. Cyclophosphamide following Targeted Oral Busulfan as Conditioning for Hematopoietic Cell Transplantation: Pharmacokinetics, Liver Toxicity, and Mortality.Biol Blood Marrow Transplant . 2007;13(7):853-862. doi:10.1016/j.bbmt.2007.03.012

43. Mohanan E, Panetta JC, Lakshmi KM, et al. Pharmacokinetics and Pharmacodynamics of Treosulfan in Patients With Thalassemia Major Undergoing Allogeneic Hematopoietic Stem Cell Transplantation.Clin Pharmacol Ther . 2018;104(3):575-583. doi:10.1002/cpt.988

44. Langenhorst JB, van Kesteren C, van Maarseveen EM, et al. Fludarabine exposure in the conditioning prior to allogeneic hematopoietic cell transplantation predicts outcomes. Blood Adv . 2019;3(14):2179-2187. doi:10.1182/bloodadvances.2018029421

45. Molina-Arcas M, Marcé S, Villamor N, et al. Equilibrative nucleoside transporter-2 (hENT2) protein expression correlates with ex vivo sensitivity to fludarabine in chronic lymphocytic leukemia (CLL) cells.Leukemia . 2005;19(1):64-68. doi:10.1038/sj.leu.2403582

46. Chen S, Wainwright DA, Wu JD, et al. CD73: an emerging checkpoint for cancer immunotherapy. Immunotherapy . Published online June 21, 2019. doi:10.2217/imt-2018-0200

47. Roh M, Wainwright DA, Wu JD, Wan Y, Zhang B. Targeting CD73 to augment cancer immunotherapy. Curr Opin Pharmacol . 2020;53:66-76. doi:10.1016/j.coph.2020.07.001

48. Yu M, Guo G, Huang L, et al. CD73 on cancer-associated fibroblasts enhanced by the A 2B -mediated feedforward circuit enforces an immune checkpoint. Nat Commun . 2020;11(1):515. doi:10.1038/s41467-01914060-x

49. Allard B, Turcotte M, Stagg J. CD73-Generated Adenosine: Orchestrating the Tumor-Stroma Interplay to Promote Cancer Growth. Dwyer KM, ed. J Biomed Biotechnol . 2012;2012:485156. doi:10.1155/2012/485156

50. Mohanan E, Panetta JC, Lakshmi KM, et al. A 5'UTR Polymorphism in NT5E Gene Influences Outcome in Patients with Acute Myeloid Leukemia Undergoing Hematopoietic Stem Cell Transplantation with Fludarabine Based Conditioning Regimen. Blood . 2016;128(22):984-984. doi:10.1182/blood.V128.22.984.984

51. Jiang T, Xu X, Qiao M, et al. Comprehensive evaluation of NT5E/CD73 expression and its prognostic significance in distinct types of cancers.BMC Cancer . 2018;18(1):267. doi:10.1186/s12885-018-4073-7

52. Vaisitti T, Arruga F, Guerra G, Deaglio S. Ectonucleotidases in Blood Malignancies: A Tale of Surface Markers and Therapeutic Targets.Front Immunol . 2019;10. doi:10.3389/fimmu.2019.02301

53. Thompson LF, Tsukamoto H, Chernogorova P, Zeiser R. A delicate balance. OncoImmunology . 2013;2(1):e22107. doi:10.4161/onci.22107

54. Tsukamoto H, Chernogorova P, Ayata K, et al. Deficiency of CD73/ecto-5'-nucleotidase in mice enhances acute graft-versus-host disease. Blood . 2012;119(19):4554-4564. doi:10.1182/blood-2011-09-375899

55. Geraghty NJ, Watson D, Sluyter R. Pharmacological blockade of the CD39/CD73 pathway but not adenosine receptors augments disease in a humanized mouse model of graft-versus-host disease. Immunol Cell Biol . 2019;97(6):597-610. doi:10.1111/imcb.12251

56. Bernasconi P, Borsani O. Immune Escape after Hematopoietic Stem Cell Transplantation (HSCT): From Mechanisms to Novel Therapies.Cancers . 2020;12(1):69. doi:10.3390/cancers12010069 
57. Fausther M. Extracellular adenosine: a critical signal in liver fibrosis. Am J Physiol-Gastrointest Liver Physiol . 2018;315(1):G12-G19. doi:10.1152/ajpgi.00006.2018

58. Tiwari-Heckler S, Jiang ZG. Adenosinergic Signaling in Liver Fibrosis. Clin Liver Dis . 2019;14(1):1-4. doi:10.1002/cld.777

Tables

Table 1: Patient Characteristics

\section{Parameters}

Age (years)

Sex (Male/Female)

Stem Cell Source Bone marrow Peripheral Blood

HLA Match Identical Mismatch

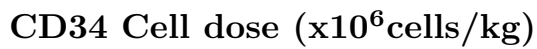

Lucarelli Classification Class I Class II Class III Vellore Risk Classification Class III High Risk Class III Low Risk

Donor type Matched sibling donor (MSD) Matched related donor (MRD) Matched unrelated donor (MUD)

Polymorphisms NT5E (rs2295890) ${ }^{\mathrm{a}}$ Homozygous reference Heterozygous variant Homozygous variant DCK (rs115447

a NT5Egenotyping was performed for 271 patients

b $D C K$ genotyping was performed for 176 patients.

NA- Not applicable

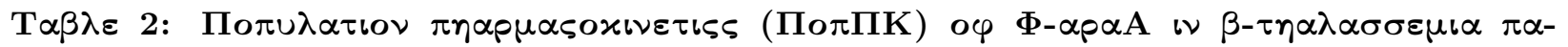

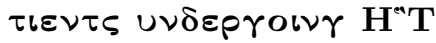

\begin{tabular}{|c|c|c|c|c|c|}
\hline Parameter & Base & RSE (\%) & rs2295890 & RSE (\%) & p-value \\
\hline$\overline{\mathrm{CL}}\left(\mathrm{L} / \mathrm{h} / \mathrm{m}^{2}\right)$ & 6.87 & 4.8 & 7.17 & 5.2 & \multirow{7}{*}{0.02} \\
\hline$\beta: \mathrm{CL}^{*}$ & & & -0.29 & 43.3 & \\
\hline $\mathrm{V}\left(\mathrm{L} / \mathrm{m}^{2}\right)$ & 18.74 & 4.5 & 18.55 & 4.7 & \\
\hline $\mathrm{Q}\left(\mathrm{L} / \mathrm{h} / \mathrm{m}^{2}\right)$ & 14.21 & 0.2 & 14.46 & 0.2 & \\
\hline $\mathrm{V}_{2}\left(\mathrm{~L} / \mathrm{m}^{2}\right)$ & 25.67 & 1.3 & 25.99 & 1.8 & \\
\hline $\begin{array}{l}\sigma \text { additive } \\
(\mu \mathrm{M})\end{array}$ & 0.06 & 20.0 & 0.06 & 15.4 & \\
\hline$\sigma$ prop CV\%) & 0.10 & 4.1 & 0.10 & 6.3 & \\
\hline-2 Log- & 1750.2 & & 1739.5 & & \multirow[t]{7}{*}{0.001} \\
\hline likelihood ${ }^{\mathrm{b}}$ & & & & & \\
\hline IIV & $(\mathrm{CV} \%)$ & RSE (\%) & (CV\%) & RSE (\%) & \\
\hline CL & 0.57 & 6.6 & 0.56 & 6.8 & \\
\hline $\mathrm{V}$ & 0.33 & 21.2 & 0.34 & 19.8 & \\
\hline $\mathrm{Q}$ & 0.70 & 11.8 & 0.71 & 9.1 & \\
\hline $\mathrm{V}_{2}$ & 0.40 & 12.8 & 0.44 & 13.5 & \\
\hline
\end{tabular}

${ }^{\text {a }}$ Covariate model: $\vartheta^{*} \exp \left(\beta^{*}\right.$ covariate $)$. rs2295890: $0=\mathrm{WT}, 1=\mathrm{HET} / \mathrm{MUT}$.

${ }^{b}$ p-value represents the significance of the change in the -2 log-likelihood (based on the $\chi^{2}$ test) relative to base model 
Abbreviations: RSE, relative standard error; CL, clearance; V, volume of distribution; Q, intercompartmental clearance; $\mathrm{CV} \%$, coefficient of variation; IIV, interindividual variation.

Table 3: Association of NT5E 5'UTR Polymorphism (rs2295890) and HCT outcome

\begin{tabular}{lll}
\hline Clinical Outcomes & NT5E 5'UTR Polymorphism (rs2295890) & NT5E 5'UTR Polymorphism (rs2295890) \\
\hline & Wild type $(\mathbf{n}=\mathbf{2 3 9}) \mathbf{n}(\mathbf{\%})$ & Heterozygous/ Mutant type $(\mathbf{n}=\mathbf{3 2}) \mathbf{n}(\%)$ \\
Rejection & $21(7.7)$ & $0(0)$ \\
Incidence of SOS* & $52(19)$ & $0(0)$ \\
TRM D+30* & $24(8.8)$ & $1(0.3)$ \\
TRM D+100* & $34(12.5)$ & $1(0.3)$ \\
EFS & $181(75.7)$ & $28(87.5)$ \\
OS & $190(78)$ & $28(87)$ \\
\hline
\end{tabular}

Abbreviations: SOS- Sinusoidal Obstruction Syndrome, TRM- Transplant related mortality, OS-Overall Survival, EFS- Event free survival.

${ }^{a}$ For TRM and incidence of SOS, ORs and p-values were calculated using penalized likelihood test-Firth logistic regression method using R. Cox regression using SPSS was used in calculating ORs and p-values for EFS, OS and Rejection.

Table 4: Comparison of F-araA PK with previous reports

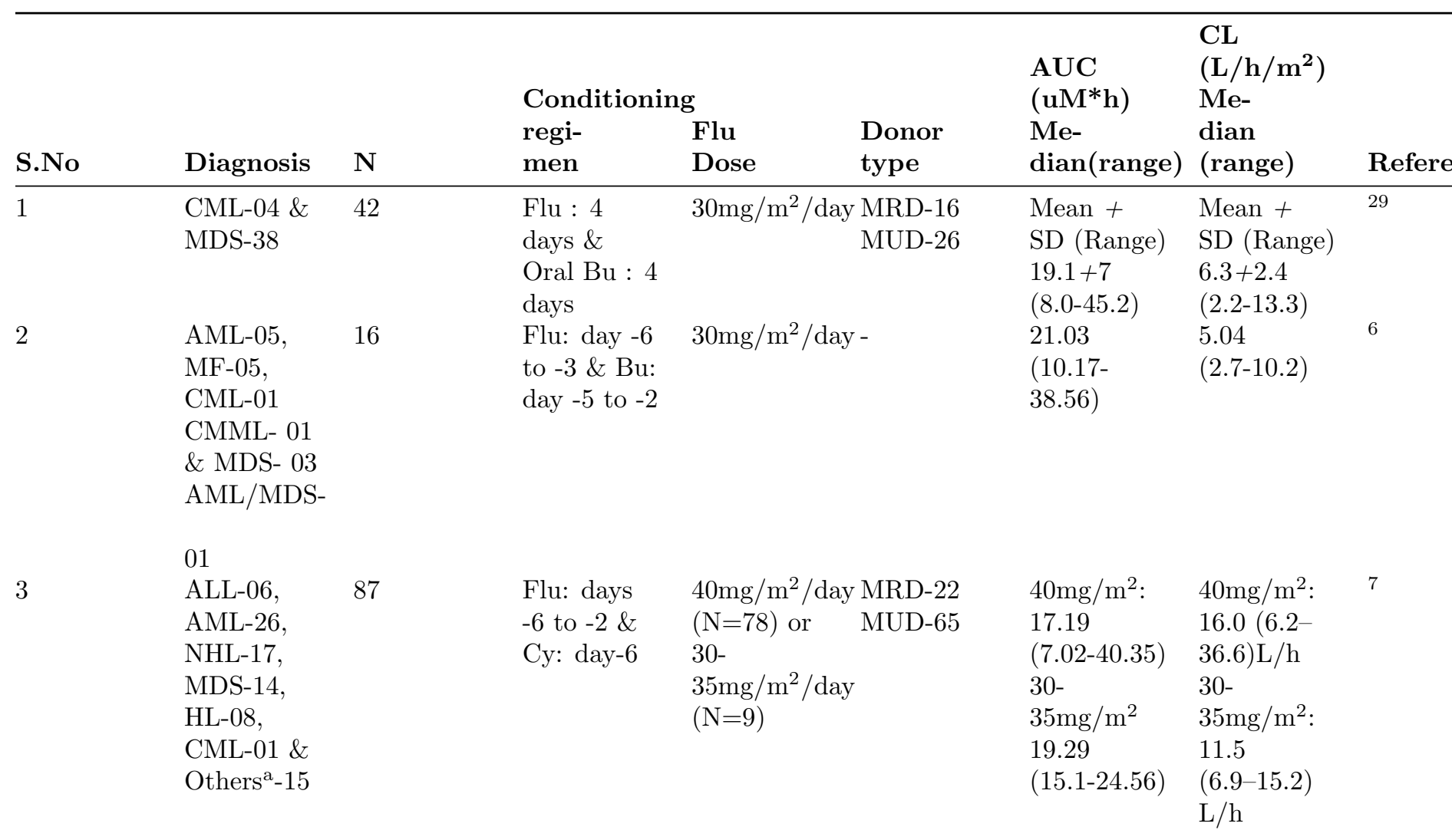




\begin{tabular}{|c|c|c|c|c|c|c|c|c|}
\hline S.No & Diagnosis & $\mathbf{N}$ & $\begin{array}{l}\text { Conditionin } \\
\text { regi- } \\
\text { men }\end{array}$ & $\begin{array}{l}\text { g } \\
\text { Flu } \\
\text { Dose }\end{array}$ & $\begin{array}{l}\text { Donor } \\
\text { type }\end{array}$ & $\begin{array}{l}\text { AUC } \\
\left(\mathrm{uM}^{*} \mathbf{h}\right) \\
\text { Me- } \\
\text { dian(range) }\end{array}$ & $\begin{array}{l}\mathrm{CL} \\
\left(\mathrm{L} / \mathrm{h} / \mathbf{m}^{2}\right) \\
\mathrm{Me}- \\
\text { dian } \\
\text { (range) }\end{array}$ & Refere \\
\hline 4 & $\begin{array}{l}\text { AML-05, } \\
\text { CML-01, } \\
\text { MDS-04, } \\
\text { MF-05 \& } \\
\text { CMML-01 }\end{array}$ & 16 & $\begin{array}{l}\text { Flu: days } \\
-6 \text { to }-2 ; \\
\text { targeted } \\
\text { daily IV } \mathrm{Bu} \\
\text { days }-5 \text { to } \\
-2 \text { \& } \text { rTG } \\
\text { on days }-3 \\
\text { to }-1\end{array}$ & $\begin{array}{l}50 \mathrm{mg} / \mathrm{m}^{2} \\
/ \text { day }\end{array}$ & $\begin{array}{l}\text { MRD-11 } \\
\text { MUD-05 }\end{array}$ & $\begin{array}{l}24.8 \\
(16.3-39.9)\end{array}$ & - & 30 \\
\hline 5 & $\begin{array}{l}-05, \text { HL-03 } \\
\& /-03\end{array}$ & 11 & $\begin{array}{l}\text { Flu: days } \\
-6 \text { to }-2 ; \\
\text { Cy: days }-6 \\
\text { and }-5 \& \\
\text { TBI day }-1\end{array}$ & $30 \mathrm{mg} / \mathrm{m}^{2} /$ day & Haplo-11 & $\begin{array}{l}16.4(10.4- \\
21.5)\end{array}$ & - & 31 \\
\hline 6 & $\begin{array}{l}\text { MDS-18, } \\
\text { AML-13, } \\
\text { CML-05, } \\
\text { CMML-02 } \\
\text { \& MF-03 }\end{array}$ & 41 & $\begin{array}{l}\text { Protocol } \\
1519 \\
(\mathrm{~N}=27) \\
\text { Flu: days } \\
-9 \text { to }-6 ; \\
\text { targeted } \\
\text { oral Bu } \\
\text { days }-5 \text { to } \\
-2 \text { Protocol } \\
2041 \\
(\mathrm{~N}=14) \\
\text { Flu: days } \\
-6 \text { to }-2, \\
\text { targeted } \\
\text { daily IV Bu } \\
\text { on days }-5 \\
\text { to }-2, \text { and } \\
\text { rATG IV } \\
\text { on day }-3, \\
\text { to }-1\end{array}$ & $\begin{array}{l}30 \\
\mathrm{mg} / \mathrm{m}^{2} / \text { day } \\
50 \\
\mathrm{mg} / \mathrm{m}^{2} / \text { day }\end{array}$ & - & - & $\begin{array}{l}\text { Protocol } \\
1519: 9.1 \\
(8-45.2) \\
\text { Protocol } \\
\text { 2041: } 7.07 \\
(4.40-10.76)\end{array}$ & 32 \\
\hline 7 & $\begin{array}{l}\text { NHL-34, } \\
\text { CLL-22, } \\
\text { AML-15, } \\
\text { MDS-10, } \\
\text { MM-09, } \\
\text { ALL- 04, } \\
\text { MF- 03, } \\
\text { AA- } 02 \\
\text { HL- } 02 \text { \& } \\
\text { PNH - } 01\end{array}$ & 102 & $\begin{array}{l}\text { Flu: days } \\
-4 \text { to }-2 \& \\
2-4.5 \text { Gy } \\
\text { TBI }\end{array}$ & $\begin{array}{l}30 \\
\mathrm{mg} / \mathrm{m}^{2} / \text { day }\end{array}$ & $\begin{array}{l}\text { MRD-24 } \\
\text { MUD-78 }\end{array}$ & $\begin{array}{l}\text { Mean }+ \\
\text { SD (Range) } \\
19.6 \pm 4.8 \\
(10-36.4)\end{array}$ & - & 33 \\
\hline
\end{tabular}




\begin{tabular}{|c|c|c|c|c|c|c|c|c|}
\hline S.No & Diagnosis & $\mathbf{N}$ & $\begin{array}{l}\text { Conditionin } \\
\text { regi- } \\
\text { men }\end{array}$ & $\begin{array}{l}\text { g } \\
\text { Flu } \\
\text { Dose }\end{array}$ & $\begin{array}{l}\text { Donor } \\
\text { type }\end{array}$ & $\begin{array}{l}\text { AUC } \\
\left(\mathbf{u M}^{*} \mathbf{h}\right) \\
\text { Me- } \\
\text { dian(range) }\end{array}$ & $\begin{array}{l}\mathrm{CL} \\
\left(\mathrm{L} / \mathrm{h} / \mathrm{m}^{2}\right) \\
\mathrm{Me}- \\
\text { dian } \\
\text { (range) }\end{array}$ & Refere \\
\hline 8 & $\begin{array}{l}\text { AA }-40 \& \\
\text { FA-13 }\end{array}$ & 53 & $\begin{array}{l}\text { Flu: days } \\
-6 \text { to }-2 \& \\
\text { Cy: days }-3 \\
\&-2\end{array}$ & $30 \mathrm{mg} / \mathrm{m}^{2} /$ day & $\begin{array}{l}\text { MSD-45 } \\
\text { AD-08 }\end{array}$ & $20(4-53)$ & $\begin{array}{l}4.7 \\
(1.2-22.4)\end{array}$ & 9 \\
\hline 9 & $\begin{array}{l}\text { HM-59, } \\
\text { PID-18, } \\
\text { HP-8, } \\
\text { IMD-22, } \\
\text { BMF-22 \& } \\
\text { EB-4 }\end{array}$ & 133 & $\begin{array}{l}\mathrm{Bu} / \mathrm{Flu} \\
\mathrm{Cy} / \mathrm{Flu} \\
\mathrm{Bu} / \text { Flu/Clo } \\
\text { Flu/ThioT/M } \\
\text { Others }\end{array}$ & $\begin{array}{l}40 \\
\mathrm{mg} / \mathrm{m}^{2} / \text { day } \\
12.5- \\
\text { Iel5mg } / \mathrm{m}^{2} / \text { day } \\
0.9-1.33 \\
\mathrm{mg} / \mathrm{kg}\end{array}$ & $\begin{array}{l}\text { MRD-38 } \\
\text { MUD-95 }\end{array}$ & $\begin{array}{l}13 \\
(11.5-15.7)\end{array}$ & $\begin{array}{l}3.3 \\
(\mathrm{~L} / \mathrm{h} / 15 \mathrm{~kg})\end{array}$ & 10 \\
\hline 10 & $\begin{array}{l}\text { AL-29, } \\
\text { JMML/ALCL- } \\
2 \text {, SAA-3, } \\
\text { CGD-3 } \\
\text { OS-2 \& } \\
\text { Others }^{\text {a }}-4\end{array}$ & 43 & $\begin{array}{l}\text { Flu: day }-8 \\
\text { to day }-3 \& \\
\text { Bu: day }-8, \\
\text { targeted } \\
\text { Bu from } \\
\text { day }-7 \text { to }-5\end{array}$ & $\mathrm{mg} / \mathrm{m}^{2} /$ day & $\begin{array}{l}\text { MRD-6 } \\
\text { MUD-34 } \\
\text { Haplo- } 3\end{array}$ & $\begin{array}{l}15 \\
(10.1-30.6)\end{array}$ & 6.47 & 34 \\
\hline 11 & $\begin{array}{l}\text { BD-69 } \\
\text { L-117 } \\
\text { LY-17 } \\
\text { MDS-32 } \\
\text { PCD-23 }\end{array}$ & 258 & $\begin{array}{l}\text { Bu/Flu: } \\
\text { day - } 5 \text { to } \\
\text { day - } 2 \\
\text { Bu/Flu/Clo } \\
\text { in children } \\
\text { with malig- } \\
\text { nancies } \\
\text { rATG in } \\
\text { MUD (day } \\
\text { - } 9 \text { for } \\
\text { children, } \\
\text { and-12 (for } \\
\text { adults) }\end{array}$ & $\begin{array}{l}40 \\
\mathrm{mg} / \mathrm{m}^{2} / \text { day }\end{array}$ & - & $\begin{array}{l}\text { Children } \\
18.4 \\
(5-36.8) \\
\text { Adults 22.8 } \\
(11.4-57)\end{array}$ & $3.2(\mathrm{~L} / \mathrm{h} /)$ & 11 \\
\hline 12 & $\mathrm{TM}$ & $169^{\mathrm{b}}$ & $\begin{array}{l}\text { Flu: day }-5 \\
\text { to }-2 \text { Treo: } \\
\text { day }-5 \text { to }-3 \\
\text { ThioT on } \\
\text { day }-6\end{array}$ & $40 \mathrm{mg} / \mathrm{m} 2 /$ day & $\begin{array}{l}\text { MSD-152 } \\
\text { MRD- } 11 \\
\text { MUD- } 29\end{array}$ & $19(3-81)$ & $7(2-38)$ & $\begin{array}{l}\text { Presen } \\
\text { Study }\end{array}$ \\
\hline
\end{tabular}

Abbreviations: AA - Aplastic Anaemia; AL- Acute Leukemia; ALCL- Anaplastic large cell lymphoma; ALL- Acute lymphoblastic leukemia; AML -Acute Myeloid Leukemia; BD- Benign Disorder; BMF- Bone marrow failure; CGD- Chronic granulomatous disease; CLL- Chronic lymphocytic leukemia; CML- Chronic Myeloid Leukemia; CMML- Chronic myelomonocytic leukemia; EB- Epidermolysis bullosa; FA- Fanconi Anemia; JMML- Juvenile myelomonocytic leukemia; SAA- Severe Aplastic Anaemia; CGD- Chronic granulomatous disease; HM- Hematologic malignancies; HL- Hodgkin lymphoma; HP- Hemoglobinopathies; IMDInherited metabolic disorders; L- Leukemia; LY- Lymphoma; MDS- Myelodysplastic Syndrome; MF- Myelofibrosis; MM- Multiple Myeloma; NHL- Non-Hodgkin lymphoma; OS- Osteopetrosis; PCD-Plasma Cell Disorder; PID- Primary immune deficiencies; PNH- Paroxysmal nocturnal hemoglobinuria; TM- Thalassemia Major. 
a Other diagnoses includes Hemophagocytic lymphohistiocytosis, Wiskott-Aldrich syndrome, Adrenoleukodystrophy and Krabbe disease.

${ }^{\text {b }}$ F-araA PK was evaluated only in 169 patients

Figure Legends:

Figure 1: Influence of NT5E/CD73 5'UTR polymorphism (rs2295890) in F-araA PK.

Association between rs2295890 genotype and post-hoc PK estimates- F-ara AUC (A) and Clearance (B). *Wt- Homozygous reference genotype, Het/Mut- Heterozygous and homozygous genotype, p-value was calculated by Mann Whitney U Test. Patients harboring NT5E promoter variant genotype exhibited significantly lower plasma F-araA CL and higher AUC compared to those with wild-type genotype.

Figure 2: NT5E 5'UTR variant genotype is associated with better OS, EFS, and reduced incidence of graft rejection

Kaplan-Meier survival curves showing associations between NT5E 5'UTR variant (rs2295890) genotype with Overall Survival (A), Event Free Survival (B), and graft rejection (C). Patients carrying the NT5E promoter variant genotype tended to have a better OS $(p=0.25)$, EFS $(p=0.12)$, and rejection-free survival $(p=0.07)$ compared to those with wild-type genotype.
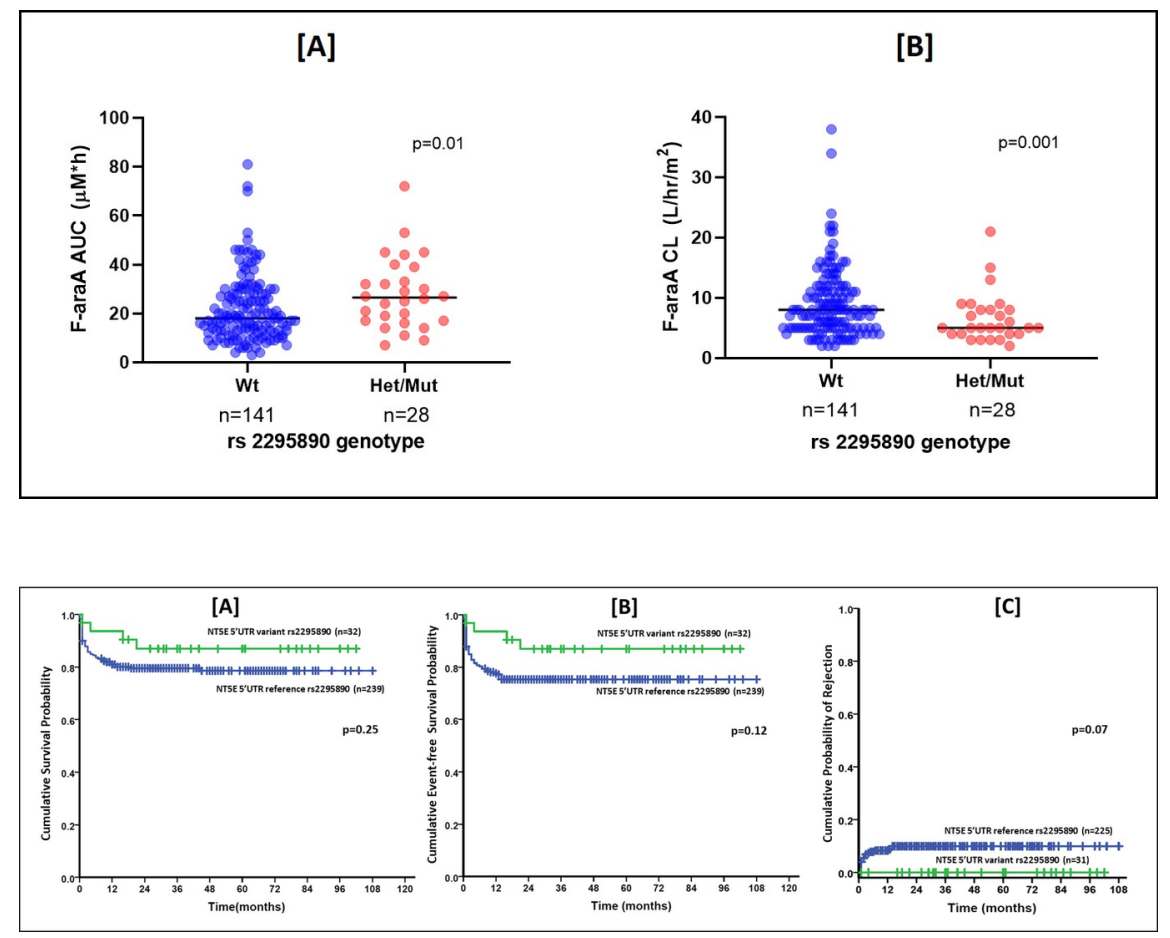